Wilfrid Laurier University

Scholars Commons @ Laurier

6-1-1987

\title{
The Politics of Fragmentation in an Age of Scarcity: A Synthetic View and Critical Analysis of Welfare State Crisis
}

Thomas O. Hueglin

Wilfrid Laurier University, thueglin@wlu.ca

Follow this and additional works at: https://scholars.wlu.ca/poli_faculty

\section{Recommended Citation}

Hueglin, Thomas 0., "The Politics of Fragmentation in an Age of Scarcity: A Synthetic View and Critical Analysis of Welfare State Crisis" (1987). Political Science Faculty Publications. 9.

https://scholars.wlu.ca/poli_faculty/9

This Article is brought to you for free and open access by the Political Science at Scholars Commons @ Laurier. It has been accepted for inclusion in Political Science Faculty Publications by an authorized administrator of Scholars Commons@Laurier. For more information, please contact scholarscommons@wlu.ca. 


\title{
The Politics of Fragmentation in an Age of Scarcity: A Synthetic View and Critical Analysis of Welfare State Crisis*
}

\author{
THOMAS O. HUEGLIN Wilfrid Laurier University
}

\section{Life After Affluence}

In 1965 Robert Lane heralded a new "politics of consensus in an age of affluence." On the basis of growth and welfare security in a managed economy, there would be an increase in mutual trust, relaxation in class awareness, and a decline of religion, racial tension and political alienation in general. ${ }^{1}$ Ten years later, Samuel Huntington was still speculating that a postindustrial society would be characterized by widespread affluence, but he was much more sceptical about the subsidence of political conflict. He foresaw that new intra-class cleavages would occur in conjunction with postmaterial value change, that an enormous expansion of political participation and mobilization would make postindustrial societies extraordinarily difficult to govern, and that the "eighteenth-century" institutions of the centralized nation-state would become enmeshed with a new sociopolitical environment of fragmentation and unrest. His only hope was that postmaterial society would not emerge in such a way and to such an extent as its theorists predicted, and hence would not need to be contained by a rather unpleasant neo-authoritative form of government. ${ }^{2}$

Another decade later, the major concern is no longer with postindustrial unrest stemming from affluence, but with the

* This article evolved from a graduate seminar co-taught with Richard Simeon at Queen's University. Critical support from Hans Kastendiek, John McMenemy, Claus Offe, Reg Whitaker, David Wolfe, and the anonymous reviewers of this JouRNAL, helped me through various stages of revision.

1 "The Politics of Consensus in an Age of Affluence," American Political Science Review 59 (1965), 874-95.

2 "Postindustrial Politics: How Benign Will It Be?" Comparative Politics 6 (1974), 163-91.

Thomas O. Hueglin, Department of Political Science, Wilfrid Laurier University, Waterloo, Ontario N2L 3C5

Canadian Journal of Political Science / Revue canadienne de science politique, XX:2 (June/juin 1987). Printed in Canada / Imprimé au Canada 
destabilizing consequences of economic and welfare state crisis. ${ }^{3}$ At what is presumably the end of the postwar period of growth and affluence, the Western industrial world has entered an age of scarcity ${ }^{4}$ characterized by a painful awareness of the limits of growth and opportunity in society, government, and the economy. Societies are haunted by structural unemployment and the decline of life chances. To find a job matching one's capabilities and ambitions can no longer be taken for granted. Governments struggle with unprecedented budget deficits which have shaken the previous belief in the universality of social safety nets. And the national economies of the industrialized West not only live with the potential threat of serious resource shortages, but also have to grapple with stiffened competition in nearly saturated markets at home and abroad.

Of course, there have been winners and losers under these new conditions of economic constraint. Some countries have recovered from the 1981-1982 recession more quickly than others, and some economic sectors have been restructured successfully, while others continue to be threatened by the prospects of lasting deindustrialization. What characterizes the new age of scarcity, then, is not so much an overall collapse of economic growth-although the growth rates of the 1950s and 1960s will hardly be reached again-but the general perception that economic expansion has become more difficult and that success is no longer open to everyone.

If this is scarcity only in relative terms, its sociopolitical consequences are nevertheless real. Class conflict has once more become more persistent. Strikes for shorter working hours and plant occupations are now responses to the threats of unemployment and poverty caused by industrial restructuring and robotization. On the other hand, new forms of mobilization and conflict have emerged which cut across the trenches of class conflict. Ecological and peace movements attempt to prevent the scope of politics being reduced again to the imperatives of national economic efficiency. And the efforts to regain such efficiency have replaced traditional capital-labour conflicts with a new pattern of socioeconomic confrontation: winning sectors, sunshine regions and the employed segment of the working force versus declining sectors, rustbelt regions and the unemployed. With painful choices of distribution to be made, and the agenda of the political engineers geared to the authoritative allocation of restructured industrial resources, the intervention state itself has become the central site of conflict and confrontation. Spurred by the previous promises of affluence and participation, the potential winners demand increasing

3 See Claus Offe, Contradictions of the Welfare State (London: Hutchinson, 1984).

4 See "Politics and Scarcity," Special Issue of International Political Science Review 4 (1983). 


\begin{abstract}
A general perception of crisis at the end of the postwar period of growth has spawned two types of theoretical response: while a conservative theory of overload focusses on ungovernability caused by postmaterialist value change, radical analysis points to the structural contradictions of the welfare and intervention state. This article suggests that the current crisis is characterized by postmaterialist persistence and structural contradictions under the conditions of economic constraint. It examines polarization and potential mobilization of fragmented postindustrial societies in the context of neo-conservative politics, and it suggests a regime of economic dualism and/or corporatism as the most likely outcome.
\end{abstract}

Résumé. La crise telle que perçue généralement depuis la fin de la période de croissance des années d'après-guerre a suscité deux types d'explication: celle de la théorie conservatrice qui met l'accent sur le phénomène de l'ingouvernabilité et du changement vers des valeurs post-matérialistes, et celle de l'analyse radicale qui fait ressortir les contradictions structurelles de l'interventionnisme d'état et de l'État providence. Le présent article caractérise la crise actuelle à la fois par la persistance des valeurs post-matérialistes et par l'existence de contradictions structurelles inhérentes aux conditions de l'économie. Il examine la polarisation sociale et les possibilités de -mobilisation au sein des sociétés post-industrielles fragmentées et ce, dans le contexte des politiques néo-conservatrices, et il propose un régime d'économie mixte et/ou de corporatisme comme étant l'issue la plus vraisembable.

state intervention on behalf of economic recovery, while the losers expect welfare payments to flow as always.

Can the "eighteenth-century" institutions of the nation-state and those of the competitive market system (which are nineteenth-century) cope with the structural and attitudinal conflicts of the twenty-first century? A rapidly expanding body of crisis literature has focussed on two types of answers to this question.

\title{
Overload Crisis
}

According to the orthodox view, there is a crisis of governability which is the result of "exaggerated demands" and "excessive democracy" in postmaterialist societies. Again the central focus is the state itself. Because of its universalist commitment to social safety and equity, the welfare and intervention state reduces the incentives to work; and because of the fiscal burden and regulatory constraint placed upon the market economy, business loses its incentive to invest. The main consequences are economic decline and fiscal crisis. While the social consequences of industrial restructuring and budget cutting are considered "normal" adjustments to the dynamic of economic change, the explanation of crisis focusses on attitudinal change: pampered by a long period of prosperity, industrial societies have developed postmaterialist values, leading them to resist necessary adjustment to leaner times and to expect too much from their governments. A temporary disjunction between postmaterialist expectations and possible achievement is seen as the root of overload crisis, and overregulation as the cause of both ungovernability and economic stagnation. If postmaterialist attitudes can be restrained along with the 
excesses of state intervention, another period of growth seems within reach. Accordingly, conservative overload analysts advocate deregulation and the readjustment of overdrawn expectations during a necessary period of investment-oriented restructuring of capitalist economies. ${ }^{5}$

\section{Structural Crisis}

Contrary to this focus on attitudinal change and overload, radical analysis on the left argues that the present crisis stems from the structural contradictions of the capitalist system itself. Overregulation and overload are not the primary cause of this crisis, but merely one aspect and manifestation of it. The contradictory nature of the capitalist welfare state is this: its socioeconomic stability rests on the fulfillment of two basic functions, accumulation and legitimation. The more private accumulation is achieved, the more public legitimization will be demanded. It is not coincidental, therefore, that the postwar expansion of the Keynesian welfare state occurred parallel to the long period of growth and prosperity. ${ }^{6}$ Feeling threatened by the squeeze on profitable accumulation, capitalism has nevertheless become dependent on the legitimizing function of welfare spending. The "embarrassing secret" and contradiction of capitalism is that while it "cannot coexist with, neither can it exist without, the welfare state.",

At the same time, however, when the state became increasingly involved in welfare spending, it also had to intervene on behalf of the economy itself, as the limits of postwar expansion became more and more apparent. The affluent state could generate the means for lavish welfare programmes from the surpluses of economic growth. It must now, under the conditions of economic stagnation, spend at both ends. One important manifestation of this is the current fiscal crisis of the state. But while neo-Marxists almost seem to agree with their neo-conservative colleagues that this fiscal crisis stems from a proliferation of expanding demands, they differ markedly as to the underlying social causes. First, they argue that the process of industrial restructuring brings forth socioeconomically induced need rather than exaggerated demands, so that the costs of necessary welfare (legitimation) inevitably grow with the likewise costly efforts to rekindle

5 See Nigel Ashford, "The Neo-Conservatives," Government and Opposition 16 (1981), 353-79; Michael J. Crozier, Samuel P. Huntington and Joji Watanuki, The Crisis of Democracy (New York: New York University Press, 1975); Anthony King, "Overload: Problems of Governing in the 1970s," Political Studies 23 (1975), 284-96; Richard Rose, "Ungovernability: Is there Fire Behind the Smoke?" Political Studies 27 (1979), 351-70; and critically, Offe, Contradictions of the Welfare State, esp. chap. 2.

6 See Ian Gough, The Political Economy of the Welfare State (London: Macmillan, 1979), 126-36.

7 Offe, Contradictions of the Welfare State, 153 (author's emphasis). 
business confidence and a healthy investment climate. Second, while much of the conventional wisdom about the detrimental effects of government spending on economic efficiency is revealed as conservative ideology, the actual accumulation of large budget deficits appears much less invoked by the growth of social expenditures than by the increase in supply side incentives and-in the case of the Reagan administration-military spending as a substitute for socially targeted Keynesianism. And the much deplored disincentives to work and invest are finally identified as inevitable side effects rather than causal agents of the current crisis: as attitudinal responses to the contradictory needs for regulatory intervention in the stagnating process of accumulation. ${ }^{8}$

\section{The Main Argument: A Synthetic Approach}

Contrary to the suggestions of overload analysts, the current crisis is not just a dilemma of attitudinal change and overregulation, and it cannot be rectified by a painful but necessary process of readjustment. Likewise, radical analysts tend to neglect the impact of postmaterialist value change on the prospects of capitalist crisis management. The underlying hypothesis of this article is that it is the persistence of postmaterialist attitudes and of deepening structural contradictions which makes advanced industrial societies so difficult to govern. A common denominator of both types of crisis theory is the general assumption that the postwar era of exceptional growth and prosperity has come to an end. Consequently, this article will first reformulate some of the key arguments in the environmental context of a crisis of scarcity. Exceptional growth during the age of affluence has made further growth increasingly difficult, and the global expansion of capitalist accumulation has exhausted both available resources and potential new markets. Under such conditions of scarcity capitalist systems have to restructure their given industrial resources instead of adding new ones.

An already visible consequence is the growing polarization of postindustrial societies. However, potential mobilization seems to be contained successfully by the crisis management of neo-conservative governments. These patterns of structural change will be examined in the context of economic restructuring efforts in the United States, Britain and West Germany. Finally, it will be argued that as these efforts can only be partially successful, postindustrial societies will be divided

8 See James O'Connor, The Fiscal Crisis of the State (New York: St. Martin's, 1973), esp. 1-12; Ramesh Mishra, The Welfare State in Crisis (Brighton: Wheatsheaf, 1984), 72-78; David Cameron, "Does Government Cause Inflation? Taxes, Spending, and Deficits," in Leon N. Lindberg and Charles S. Mayer (eds.), The Politics of Inflation. and Economic Stagnation (Washington: The Brookings Institution, 1985), 224-79; Vicente Navarro, "The 1980 and 1984 U.S. Elections and the New Deal," in Ralph Miliband et al. (eds.), Socialist Register 1985/86 (London: Merlin, 1986), 186-91; Offe, Contradictions of the Welfare State, 263-66. 
into a restored core of economic efficiency, and a periphery of socioeconomic marginalization. The most likely scenario for the foreseeable future seems to be a politics of fragmentation which tries to stabilize bifurcated postindustrial societies by a strategy of economic dualism and/or corporatist modes of conflict regulation.

\section{A Crisis of Scarcity}

If the development of market capitalism has always been accompanied by state interventionism, and the stability of liberal societies has always depended on their protection from the "whims of the market," should this structural contradiction now lead to a particularly disruptive welfare state/ungovernability/fiscal crisis? One important answer may indeed lie in the preceding phase of exceptional growth and stability which heightened expectations while exhausting the potential for further expansion. Having now returned to the "normalcy" of capitalist development, Lane's vision of consensual affluence may have been nothing but a short-lived dream.

Another important answer must be seen in the historically accelerating growth of direct state intervention and the uncontrolled proliferation of non-market mechanisms and organizations at the same time. Capitalism finds itself in the role of the sorcerer's apprentice: it no longer knows how to switch off the overflowing powers of the welfare and intervention state which it called into being for its own support and legitimation. In order to understand better how the capitalist state was manoeuvred into this situation, three phases of postwar development ought to be distinguished.

First, during the 1950s an intensive reconstruction of the world economy took place under extremely favourable conditions of capital accumulation and concentration. Wages remained low as long as there was an immense reservoir of wage labour including millions of refugees and later migrant workers. The threat of the cold war dampened industrial conflicts. An abundant supply of cheap raw materials and energy boosted profitability as well as the new arrangements of free trade under US dominance. Industrial production became primarily geared to export markets.

Second, by the 1960 s the booming postwar economies had absorbed most surplus labour and near full employment was reached. Real wages began to rise rapidly, labour organizations gained status and power, and industrial relations became the main focus of the Keynesian welfare state. Its task was to tie "mass consumption levels to rising productivity levels through a pattern of collective bargaining." 10 The state became

9 Karl Polanyi, The Great Transformation (Boston: Beacon Press, 1957), 176.

10 David Wolfe, "The Crisis in Advanced Capitalism: An Introduction," Studies in Political Economy 11 (1983), 11. 
responsible for wage and welfare increases and rising productivity at the same time. It was during this period of the 1960s and 1970s that "the social transformation of advanced capitalist states accelerated": state interventionism became dominant, total public expenditure exceeded 50 per cent of Gross National Product, and welfare spending 50 per cent of total public expenditure in several Western countries. ${ }^{11}$

Third, in the 1980s we have seen the emergence of yet another phase. In order to cope with economic crisis and budget deficits, conservative governments in Britain, West Germany and the United States have embarked upon a precarious and contradictory path of thinning out previously undisputed social safety nets and targeting a selective reconstruction of their ailing economies. They follow the neo-liberal advice that the overdrawn expectations of postmaterialist welfare societies must be curbed in order to channel scarcer financial resources towards more productive investment.

What if Western industrial societies have reached a level of aggregate complexity which makes such readjustment well-nigh impossible? It was the earlier phase of postwar economic expansion and affluence which allowed the interventionist success of the Keynesian welfare state. Mass production and productivity gains were tied to parallel increases in wages and mass consumption. It seems doubtful that a strategy of negative Keynesianism, that is, the adjustment of mass production and mass consumption to a lower aggregate level, can be administered "democratically." It seems likewise improbable that entire industrial societies can be drastically restructured in order to meet the profitability criteria of capital. According to our underlying hypothesis it is the mutually reinforcing character of postmaterialist persistence and deepening structural contradictions under conditions of scarcity which accounts for the current crisis.

\section{Postmaterialism and Scarcity}

Three interrelated themes have dominated the conservative crisis discussion in recent years: governmental overload, postmaterialist value change, and the necessity of national economic reconstruction. The crisis report to the Trilateral Commission summed up causes and culprits: the ungovernability of overloaded governments stems from excessive demands and overindulgence; wealth and education have spawned an "adversary culture" among intellectuals and the media, delegitimizing authority in capitalist democracies; excessive democracy is replacing healthy democratic apathy; these intrinsic challenges to governance prevent postmaterialist societies from adjusting to rapid

11 Goeran Therborn, "Classes and States," Studies in Political Economy 12 (1984), $32-36$. 
economic change, and especially from meeting the external challenge of competition and interdependency in the international marketplace. ${ }^{12}$

The most powerful and widely accepted explanation of the new politics of ungovernability has come from Inglehart's theory of postmaterialist change. Defining postmaterialism as the intergenerational shift from acquisitive to participatory political values, ${ }^{13}$ Inglehart has also diagnosed the consequences of such behavioural change: the potentially self-defeating neglect of the "economic base on which postmaterialism ultimately depends" by the "anti-industrial outlook of some of the movement's ideologues." 14 According to this view it is the anti-industrial attitude which prevents postindustrial societies from taking on the challenge of international economic competition, and it is here that governments must find their new role: in administering reindustrialization, re-education, and the reallocation of necessary economic losses. ${ }^{15}$ The bottom line is that the efforts of economic restructuring are frustrated by the persistence of postmaterialist values. While industrial states struggle with economic crisis, their societies are still guided by the earlier experience of affluence and welfarism. Based on the periodicity of intergenerational change alone, such views neglect the impact of the economic crisis itself. They need to be modified and extended in several ways.

(1) While postmaterialism gained momentum during the affluent 1960 s, it was the crisis of the 1970s which made it so persistent when the earlier promises of success, equity and participation remained unfulfilled. As one study of the Green Party in West Germany has shown, the postmaterialist partisan realignment appears as "an immediate consequence of the economic recession." Green voters are usually both "young and better educated." In the wake of "drastic reductions in public spending" and sinking "employment opportunities," the frustrations of this intra-generational elite led to partisan dealignment, and to the formation of alternative channels of participation. In other words, postmaterialism in the 1980 s indicates a crisis-induced "conflict within rather than between generations." 16

12 See Crozier et al., The Crisis of Democracy, 1-9 and 113-15.

13 "The Silent Revolution in Europe: Intergenerational Change in Post-Industrial Societies," American Political Science Review 65 (1971), 994-95.

14 "The Changing Structures of Political Cleavages in Western Society," in Russell J. Dalton, Scott C. Flanagan and Paul Allen Beck (eds.), Electoral Change in Advanced Industrial Democracies (Princeton: Princeton University Press, 1984), 69.

15 See Amitai Etzioni, An Immodest Agenda (New York: McGraw-Hill, 1983); Chaimers Johnson (ed.), The Industrial Policy Debate (San Francisco: ICS Press, 1984); Clark Kerr, The Future of Industrial Societies (Cambridge: Harvard University Press, 1983); Jan-Erik Lane (ed.), State and Market (London: Sage, 1985); Orlando Fals Borda (ed.), The Challenge of Social Change (London: Sage, 1985); Alice M. Rivlin (ed.), Economic Choices 1984 (Washington: Brookings Institution, 1984).

16 Wilhelm P. Buerklin, "Value Change and Partisan Realignment in West Germany 
(2) The effects of economic scarcity have been reinforced by a social scarcity of generalized growth. As Fred Hirsch argued, economic growth has mainly worked as a "superior substitute for redistribution." It has brought "mass consumption to the point where it causes congestion in the widest sense." The individual value and opportunity of higher education declines, for example, when such education becomes available at a mass level. At a higher aggregate level, distributional conflict is intensified rather than relieved: "If everyone stands on tiptoe, no one sees better." The economic crisis is also a crisis of growth. Attitudinal change does not only stem from the experience of excessive consumerism, it is heightened and hardened by the devaluation of individual positional achievements in crowded industrial societies. ${ }^{17}$

(3) Insisting that the capitalist reconstruction project must be shielded against the perils of "excessive democracy," the overload theorists advocate a parallel programme of societal re-education geared to the traditional values of family and group life..$^{18}$ They forget that it was the same entrepreneurial spirit they seek to rekindle which helped to erode the traditional value system of private group life and political apathy. Deploring the fragmentizing effects of excessive individualism, they overlook that it is the business ethic which "tends to reduce social relationships to a 'cash-nexus' destroying earlier ideas of an organic society" without "putting anything in their place." ${ }^{19}$ When the explicit allocation of economic losses is on the agenda, there is little hope that the appeal to family-oriented complacency will be crowned with success.

\section{Scarcity and the State}

The notion of ungovernability as a crisis of overload implies that the problem can be overcome by adequate restructuring and selective retargeting: we must become leaner, harder and tougher. It is on this that the planners and strategists of most Western liberal democracies have come to place their hope. However, at least two aspects of this structural crisis seem to be persistent: an economic crisis of surplus capacities and a fiscal crisis of budget deficits.

The postwar modernization of the European and Japanese economies under US hegemony, and the eventual know-how transfer to the developing world, led to a novel degree of world productivity. The

1970-1983," paper presented at the annual meeting of the American Political Science Association, Washington, 1984, 9-12.

17 Social Limits to Growth (Cambridge: Harvard University Press, 1976), 2-10; compare Adrian Ellis and Krishan Kumar (eds.), Dilemmas of Liberal Democracies (London: Tavistock, 1983).

18 Etzioni, An Immodest Agenda, 361; see also 3-25 and 342-71.

19 Robert Skidelsky, "The Decline of Keynesian Politics," in Colin Crouch (ed.), State and Economy in Contemporary Capitalism (New York: St. Martin's, 1979), 64. 
United States, Europe, and Japan have become serious competitors in a world market no longer dominated by one economic superpower. While the debt-ridden countries of the Third World offer very limited possibilities of additional market expansion, some of the newly developing countries have become additional competitors in the already overcrowded old markets. What had earlier begun in the United States eventually became a central feature of all modernized economies: their success was increasingly tied to the parallel growth of mass production and mass consumption. The "globalization" of economic expansion ${ }^{20}$ was facilitated by the internationalization of capital and by free trade. But eventually this system became a victim of its own success: surplus capacities in declining sectors have led to neo-protectionism, and markets are becoming increasingly saturated. The limits of growth are also dictated by the surplus capacities of overloaded world markets.

What the conservative agenda overlooks most of all are these international constraints of economic recovery. Domestic restructuring will augment the problems and conflicts of international competition. What will be gained at home may be lost in the world market. In other words, if all the industrial states of the West stand on tiptoe, no one will be further ahead. As the reality of neo-protectionism underneath the rhetoric of free trade reveals, capitalist states are faced with the globalization of those same structural contradictions internationally which could only be contained domestically by steady economic growth and the availability of unexhausted markets.

Parallel to administering the expanding dynamic of mass production, the state had also become responsible for the maintenance and stabilization of mass consumption. But when the postwar boom ended, the limitations of Keynesian interventionism became apparent. Contrary to the ideological assertions of the business community, it was the growing disjunction of capitalist production and mass consumption, and not government intervention, which caused economic stagnation and inflation at the same time. Deficit spending was a response to the persistent demands of consumers and producers.

On the one hand, the demands of organized labour (strengthened under the earlier regime of near full employment) forced the state to expand its social policy programmes, the costs of which skyrocketed when massive unemployment became the consequence of recessionary strategies designed to curb inflation. On the other hand, the state had to embark upon a massive programme of economic restructuring. Business confidence increasingly had to be pampered by subsidies and tax breaks. It does not require much theoretical sophistication to see how this emerging pattern of double spending (for accumulation and

20 See Alain Lipietz, "The Globalisation of the General Crisis of Fordism," SNID Occasional Paper (Kingston: Queen's University, 1984), esp. 4-14. 
legitimation) would result in a fiscal crisis of the state. Instead of supplying the public purse with tax funds for the state's welfare activities, business itself has become a recipient of public spending. The fiscal budget deficits resulting from such double spending may well be regarded as the ultimate manifestation of the structural contradictions in which the capitalist state finds itself enmeshed. In order to overcome the political resistance to structural change, the effects of which are sectoral decline and unemployment, the state not only has to finance transfer payments to the new growth sectors, but also supply increasing levels of welfare for the structurally displaced and unemployed. If, on the other hand, the state wants to contain these costs of welfare, it ends up financing not only growing sectors but also subsidizing declining ones. ${ }^{21}$

While a persistent fiscal crisis must obviously undermine the efficiency of the capitalist intervention state, the creeping erosion and delegitimization of the institutions of liberal democracy may be even more dramatic consequences. The state can only administer a selective programme of change if it can deal directly with its crucial participants. In doing so, "there is every reason for [these] participants to keep their delicate exchange of proposals, information and threats as remote as possible [...] from the public eye." The parliamentary process is reduced in its "ability to provide for the articulation of conflict." Consequently, those who are left out by this new deal of economic reconstruction may seek "alternative channels of conflict," and the state may have to respond to this further erosion of democratic legitimacy by "other sources" of political management than "the democratic political process." 22

There is widespread consensus as to the deplorable state of economic policy-making at the present stage, but opinions are opposed as to causes and cures. Overload theorists believe that the crisis can be overcome by adequate restructuring, however painful it may be. Looking at the strength and resilience of neo-conservative regimes, they argue that the cause of overload and the persistence of economic stagnation is not opposition to the prescribed change, but rather indifference and lack of co-operation; consequently, the cure is to be found in reasserting political authority, moral re-education and, hopefully, a "spurt of economic growth." ${ }^{23}$ For neo-conservatives the ongoing crisis is little more than a temporary side-effect on the road to necessary modernization, ${ }^{24}$ and a good deal of the persistent success of

21 Compare John Zysman, "Inflation and the Politics of Supply," in Lindberg and Mayer (eds.), The Politics of Inflation and Economic Stagnation, 147-48; and on the causal nexus of inflation and deficit spending, see David R. Cameron, "Does Government Cause Inflation? Taxes, Spending, and Deficits" (ibid., 224-79).

23 Rose, "Ungovernability," 369.

24 Compare Robert B. Reich, "Toward a New Public Philosophy," The Atlantic 
neo-conservative regimes, therefore, stems from their media incantations that the end of the tunnel is in sight.

The theorists concerned with the irreconcilable contradictions of the capitalist economy, on the other hand, have little faith in the success of the neo-conservative agenda: "Coming in the wake of liberal failure, conservative policies are popular, but also impotent; tension-relieving, but not ultimately satisfying; and nostalgic, if unable to face the future." 25 This scepticism stems from a radically different analysis of the causes of crisis. Radical political economists see the present crisis as one of capitalism itself. Maybe this crisis can be patched over once again by incrementalist crisis management, but certainly there will be no cure in the long run.

It seems clear that the capitalist state has become enmeshed in contradictory activities which were not foreseen by the "logic of Keynesianism," when governments were "to determine the level of output, not what was produced, who produced it and to whom it went." ${ }_{26}$ The problem of the neo-conservative agenda seems to be that it attempts to prescribe a definite cure which is hardly based on a solid analysis of the causes of the present crisis. The radical left, on the other hand, appears to be much better equipped for providing such an analysis, but fails to give precise directions as to where late capitalist societies might move from here. Looking next at the patterns of structural change which are already visible, however, some such directions can be suggested.

\section{Patterns of Structural Change}

According to the orthodox view, ungovernability and economic crisis stem from the deformations of the marketplace through the interventionist welfare state. This "politicization of economic life" is at the same time caused and perpetuated by the participatory demands of a postmaterialist clientele cushioned against the hardships of competitive work through the welfare achievements of this very same system of politicized interventionism. ${ }^{27}$ In the light of these assumptions the orthodox prescription for betterment is relatively obvious. It mainly consists of a belt-tightening and re-educative "public philosophy," and a corrected and revitalized market mechanism "for the promotion of

Monthly, May 1985, 68-79; Peter Steinfels, The Neoconservatives (New York: Simon and Schuster, 1979); and Michael Walzer, "Nervous Liberals," New York Review of Books, October 11, 1979, 5-9.

25 A. Wolfe, "Sociology, Liberalism, and the Radical Right," New Left Review 128 (1981), 22.

26 Skidelsky, "The Decline of Keynesian Politics," 57.

27 See Melvyn Krauss, " 'Europeanizing' the U.S. Economy: The Enduring Appeal of the Corporatist State," in Johnson (ed.), The Industrial Policy Debate, 71-90. 
social ends." ${ }^{28}$ The essence of the revitalization programme is, in the words of Aaron Wildavsky, "intensification of economic growth now in order to provide more for redistributive and environmental purposes later." ${ }^{29}$ Some instrumental differences exist as to how the recovery programme can be achieved: while neo-conservatives claim to rely solely on a deregulated market system, neo-liberals want to allow for some degree of "semi-targeted" 30 state interventionism. There must be serious doubts as to whether the prescribed cure in either variety can work. The revitalization of the market as a self-regulating system of reproduction alludes to a myth even under the most favourable economic conditions, and in its semi-targeted form belies its own pretension. The distinction of private and public has always been a "crude fiction" and, as Karl Polanyi pointed out, the realization of a purely private market system would amount to nothing less than a "satanic mill.",31

Under conditions of scarcity, however, the attempt to target market reconstruction through the actions of an already overburdened state simply "mocks" political reality. ${ }^{32}$ Low profitability and declining growth have made the state vulnerable to the delegitimizing effects of selectivity. Concentrating its efforts on "winners," the state not only frustrates losing sectors and segments of society, it also undermines its autonomy and control over those segments of organized capitalism on which its political power depends. On the one hand, as the winner-loser strategy cuts across classes (skilled workers versus unemployed, for instance, or big business versus small business), the collective bargaining scheme tends to break down because the organizational elites may lose control over their rank and file. ${ }^{33}$ On the other hand, the big private interests find their bargaining position formidably improved: because the survival of the nation economy in the volatile international marketplace depends on their co-operation, they can successfully demand increased state support and put national economic planning under the constraints of their preferences. ${ }^{34}$

28 Ashford, "The Neo-Conservatives," 362.

29 "Squaring the Political Circle: Industrial Policies and the American Dream," in Johnson (ed.), The Industrial Policy Debate, 42.

30 See Etzioni, An Immodest Agenda, 315.

31 The Great Transformation, 73.

32 See Robert L. Heilbroner, The Nature and Logic of Capitalism (New York: Norton, 1985), 105-06.

33 Compare Wolfgang Streeck, "Neo-Corporatist Industrial Relations and the Economic Crisis in West Germany, " in John H. Goldthorpe (ed.), Order and Conflict in Contemporary Capitalism (Oxford: Oxford University Press, 1984), esp. 303-14.

34 Compare Allessandro Pizzorno, "Interests and Parties in Pluralism," in Suzanne Berger (ed.), Organizing Interests in Western Europe (Cambridge: Cambridge University Press, 1983), 267-68. 
While losing control over the economy in its entirety, national policy-making falls victim to blackmail from powerful domestic and multinational corporations, on the success of which governments have become increasingly dependent. The state's capacity to use its fiscal and administrative expertise in order to regulate necessary economic change, independently from competing business factions and class conflict, diminishes. Selectively targeted restructuring under fiscal constraint and geared to the whims of the world market raises doubt as to the widely accepted concept of the state's "relative autonomy." 35 The controversial strategy of selective restructuring not only ties the state to the dominant interests of the economy, it also increases rather than diminishes the problem of "overload." The restructuring process itself proves costly, as the free market strategy "paradoxically" requires "drastic intervention." Moreover, as capital spending is redirected towards cost-cutting rationalization investment, persistent mass unemployment may be "ultimately driving up expenditures on those programs," the costs of which were to be reduced in the first place. ${ }^{36}$

It is in this context that it becomes necessary to re-examine one of the overload theorists' basic premises: that an increase in participatory demands equals a shift from acquisitive towards postmaterialist values. The belief in unlimited growth during the affluent 1960s had created postmaterialist expectations which turned out to be "overdrawn" when the first signs of constraint and crisis showed in the 1970s. After the deep recession of the early 1980 s, however, with the prospects of lasting unemployment and rising social insecurity, political mobilization may well have become a prerequisite for material survival. This does not necessarily mean that a lasting destabilization of late capitalist societies is imminent. But the sociopolitical containment of potential mobilization has become part of the neo-conservative agenda of crisis management.

\section{Contained Mobilization}

After a period of continued growth and political stability in the 1950s and 1960 s, the "massive politicization and mobilization" ${ }^{37}$ of the late 1960 s and 1970s came as a shock to those who had become accustomed to the "politics of consensus in an age of affluence." The rise of new regional and social movements ${ }^{38}$ seemed to confirm the postmaterialist

35 Compare Leo Panitch, "The Role and Nature of the Canadian State," in L. Panitch (ed.), The Canadian State (Toronto: University of Toronto Press, 1977), 7-8; and the debate between Leslie A. Pal and Carl J. Cuneo in this Journal 19 (1986), 71-103.

36 Teresa Amott, "The Politics of Reaganomics," in Edward Nell (ed.), Free Market Conservatism (London: Allen and Unwin, 1984), 173-74.

37 Suzanne Berger, "Politics and Antipolitics in Western Europe in the Seventies," Daedalus 108 (1979), 27.

38 See Edward A. Tiryakian and Ronald Rogowski (eds.), New Nationalisms of the Developed West (Boston: Allen and Unwin, 1985); Fals Borda, The Challenge of 
hypothesis of persistent attitudinal change resulting from the years of affluence. However, the emphasis on attitude overlooked the mobilizing effects of structural change. As Huntington had pointed out, the unreformed institutions of the traditional nation-state would fail to accommodate the new intra-class cleavages in highly complex postmaterialist societies. ${ }^{39}$ This line of argument can now be expanded.

(1) With the end of growth and the necessity of reslicing the pie, one important factor of mobilization was the growing consciousness of the inherent inequality of state intervention. The selectivity of the asymmetrical restructuring programme accelerated the formation of fragmented interests.

On the side of organized labour, the new dividing line lies between those who can hope for job stabilization through collective action and those for whom unemployment has rendered such action meaningless. When structural unemployment must be considered as a persistent factor of economic life, a wedge is driven into the collective spirit of labour. Trade union solidarity must decline with its capacity to speak for and defend the working force in its entirety. Once again attitudinal change appears as a consequence of declining employment chances.

On the side of organized capital the picture is equally dismal. As the restructuring and modernization project increasingly becomes dependent on the alliance of state bureaucracy, big business and scientific technocracy, the declining segments of business become increasingly frustrated. And the domestic links between core and spin-off industries become brittle when multinationals increasingly shift their operations to the cheaper labour markets abroad. The coherent support of national industrial strategies no longer seems plausible. The globalization of capitalist production favours the formation of a corporatist bloc of dominant economic interests, and it leads to the dualization of national economies.

Caught in the contradictory and fragmented expectations of capital and labour, the state appears paralyzed over such issues as protectionism, subsidization and/or free trade. The recent appeals of conservative governments to small business initiative highlight this fragmentation. Since small businesses can hardly substitute for the evasive multinationals as a new vanguard of national economic consolidation, their status appears to be reduced to that of-albeit demanding-recipients of a new kind of economic welfare.

(2) What further exacerbates fragmented interest formation is the increased visibility of selective state intervention. Big government, whether in its interventionist or, "paradoxically," in its free market

Social Change; and Jo Freeman (ed.), Social Movements of the Sixties and Seventies (New York: Longman, 1983).

See above, note 2 . 
variety, increases the number of dependency-relationships for which it is held responsible. When it is met at the same time with a declining capacity to fulfill its obligations due to growth failure and fiscal constraints, big government becomes exposed and vulnerable to the electoral blackmail of a fragmented clientele with contradictory expectations. For once, the orthodox picture of overloaded governments caught in a world "at once more demanding and more intractable" 40 seems to tally with the radical view of a "disjunction" between the "declining capacity of political institutions" and the "growing politicization of everyday life." ${ }^{41}$ But the congruence is misleading: while overload pessimists concede that it will be difficult to reduce overload due to hardened expectations and electoral constraints, radical pessimists suggest that this demand overload is perpetuated by the very efforts to overcome the intractability of late capitalism.

In either case speculations as to the final destabilization of late capitalist systems seem premature. What is surprising now, after the deep recession of the early 1980 s, is not the fragility of the capitalist state, but its apparent resilience. For the time being, neo-conservative governments which openly proclaim and enact drastic change are enjoying electoral support. Is social and political destabilization an intellectual chimera of political theorists bored with the political apathy of postindustrial societies and the blandness of their political leaders? Rather, it is the blandness of current political rhetoric, and the media incantations of imminent economic recovery, which are meant to divert public attention from the growing cracks in the social fabric of postindustrial societies. The tactic is one of conflict internalization and externalization.

What went on behind the "teflon shield" of the Reagan presidency was the internationalization of growing cleavages "through complex lobbying, deals and tradeoffs." ${ }^{42}$ Using the external factor of a tough foreign policy stance as a certificate of strong leadership, the Reagan administration aimed at a winning coalition of neo-conservative ideological retrenchment and neo-liberal economic success. In Britain the "iron grip" of Margaret Thatcher has weathered the responsibility for an unprecedented postwar recession by rallying a traditionally collective spirit against the internal and external enemy. Crushing the unions and winning the Falklands war, she could proclaim that "Britain is great again." Behind the "smokescreen" of the monetarist "miracle that never happened" looms a political agenda of restructuring: a "free economy and strong state." ${ }^{43}$

40 King, "Overload," 294.

41 Berger, "Politics and Antipolitics in Western Europe," 30.

42 Amott, "The Politics of Reaganomics," 173.

43 Geoff Hodgson, "Thatcherism: The Miracle That Never Happened," in Nell (ed.),

Free Market Conservatism, 184-91. 
Despite considerable differences in style and goals-short-term economic success through multiple tradeoffs in the one case, and the fundamentalist reorganization of politics and economy through the resolute promotion of an ideological counter-revolution in the other ${ }^{44}$ - there is a common denominator of strategy: to contain the increasing rifts of socioeconomic and structural fragmentation. What has stabilized neo-conservative policy-making is not so much a sustained level of mass support as the cross-cutting quality of policy outcomes which prevents effective counter-strategies through the traditional channels of opposition.

The case of Britain is instructive: while mass unemployment divides the party/union movement on the left, the traditional cleavage between financial capital and industrial manufacturing is deepened through monetarism. ${ }^{45}$ As Colin Leys has demonstrated, it is this incongruence between class structure and socioeconomic opposition which has stabilized Thatcherism thus far: while being devastated and decimated, the manufacturing community cannot bring itself to vote other than Conservative. ${ }^{46}$ In Reagan's America, on the other hand, the looming outbreak of the sunbelt-frostbelt conflict is mainly contained by the lack of any credible (party) alternative. In Congress the impact of economic restructuring is a cross-cutting issue which prevents effective opposition. Outside, the "rainbow coalition" of losers is still in the process of learning the lesson of collective solidarity. Shrewdly manipulating these cross-cutting cleavages, the president remains insulated from direct responsibility.

The present electoral success of neo-conservative regimes does not contradict the earlier diagnosis of a potential mobilization of fragmented interests in late capitalist societies. This success has been based on the generalized promise of change in times of crisis and scarcity. Change has been administered, but it has increased the contradictions of accumulation and legitimation. For the time being, the threat of socioeconomic destabilization seems under control because the grievances of the new groups of losers cut across the traditional lines of (class) conflict, and can be contained through strategies of political subterfuge, coalition-building and log-rolling. But a growing

44 See Steven E. Schier and Norman J. Vig, "Economic Performance and Mass Support: The Thatcher and Reagan Regimes," in N. J. Vig and S. E. Schier (eds.), Political Economy in Western Democracies (New York: Holmes and Meier, 1985), 257-83.

45 See Peter A. Hall, "Patterns of Economic Policy: An Organizational Approach," in Stephen Bornstein, David Held and Joel Krieger (eds.), The State in Capitalist Europe (London: Allen and Unwin, 1984), 21-43; and Bob Jessop, "The Transformation of the State in Post-War Britain," in Richard Scase (ed.), The State in Western Europe (London: Croom Helm, 1980), 30-33.

46 "Thatcherism and British Manufacturing: A Question of Hegemony," New Left Review 151 (1985), 5-25. 
polarization of late capitalist societies can no longer be denied. Because of the structural effects of unemployment and declining life chances, this polarization is linked to individual social status and sectoral occupation rather than class, and according to the spatial division of labour in advanced industrial systems, it tends to be tied to economic regions. When socioeconomic and regional polarization become mutually reinforcing, its "conflict-generating potential" may indeed outweigh the "conflict-resolving capacity" 47 of conservative crisis management.

\section{Polarization}

The efforts of curtailing welfare expansion to the requirements of "restored business confidence," and of restructuring national economies to the imperatives of an internationally competitive "investment climate" began before neo-conservative governments swept to power. Thatcher continued a path of wage restraint, deflation and unemployment already visible under her Labour predecessor Callaghan, and Reagan's policy of tight money control along with supply-side economics had already been initiated by Carter. ${ }^{48}$

While the overall analysis of policy-making in crisis-ridden capitalist economies may indicate that "the political composition of governments does not make a difference," 49 a point can be made that neo-conservative regimes do make a difference, at least in specific policy fields and problem areas. Their present efforts of economic restructuring aim at, find more acceptable than before, or at least treat as dependent variables, such polarizing structural change as (1) a substantial degree of social restratification, (2) a deliberate dynamic of sectoral deindustrialization, and (3) a reinforcing pattern of spatial disintegration. The record shows both the main strength and liability of the neo-conservative restructuring project. On the one hand, there is decisive action. Reaganomics and Thatcherism contrast sharply with the previous policy style of incrementalist crisis management which rapidly lost its appeal to payers and recipients of the welfare state. On the other hand it becomes clear that "any decisive solution of the economic problem will have to be a sociopolitical, rather than simply a technical one, and one out of which clear winners and losers will emerge."

(1) Social restratification is incurred through the acceptance of increasing income inequality and of lasting mass unemployment. In the

47 Offe, Contradictions of the Welfare State, 164.

48 See Reich, "Toward a New Public Philosophy," 72-73; and Leys, "Thatcherism and British Manufacturing," 88-89.

49 Manfred G. Schmidt, "The Welfare State and the Economy in Periods of Economic Crisis: A Comparative Study of Twenty-Three OECD Nations," in Vig and Schier (eds.), Political Economy in Western Democracies, 148-49.

50 John Goldthorpe, "Problems of Political Economy After the End of the Post-War Period," unpublished manuscript, Nuffield College, Oxford, 1982, 40. 
United States, budget cutting under the Reagan administration has significantly contributed to a new record level of poverty. Due to administration policies, the growing income inequality has particularly affected such problem groups as black and female-headed families; while the top 40 per cent of income earners gained substantially in real disposable income (8.7\% for the top $20 \%$ between 1980 and 1984), the bottom 40 per cent lost considerably $(-7.6 \%$ for the poorest quintile). Thatcher's policies in Britain have also resulted in a major upward redistribution of income. Again, while the wealthiest 20 per cent of households gained in real disposable income, the poorest quintile suffered a loss of 9.7 per cent (between 1978-1979 and 1981-1982). The case of West Germany underlines the impact of lasting unemployment itself on socioeconomic polarization. While unemployment soared from 3.7 to 9.4 per cent (1980-1984), federal contributions to unemployment assistance and eligibility standards have been continuously curtailed at the same time. As a consequence, the number of unemployment benefit recipients has decreased by 13.3 per cent during the same period. While the average duration of unemployment increased from 3.7 to 11.6 months (with $53 \%$ unemployment of more than 2 years), the level of overall payments has been lowered, and federal contributions per unemployed have been more than cut in half..$^{51}$

(2) Sectoral deindustrialization has become a major concern in industrial policy debates. While the newly established market orthodoxy believes in the creative destruction of entire segments of the their economies, Keynesians and radicals alike see irreparable damage resulting from the reduction of structural diversity. The profit and investment squeeze on manufacturing in particular appears as a consequence of both recession and high interest rates. But then these were in part calculated monetarist strategies in order to bring down inflation. While creditors and "high-tech" sectors gained, manufacturing bore the brunt of such destructive creativity. Due to the mismatch between the skill requirements of the manufacturing and "high-tech" segments of the work force, structural and lasting unemployment is exacerbated further. While some of this unemployment can be absorbed in the service sector as a last resort for job creation, the result is a deskilling of labour and downgrading of wages and living standards, in part due to the ongoing politics of service deregulation. The politics of tight money finally leads to an accelerated

51 See for details: John L. Palmer and Isabel V. Sawhill (eds.), The Reagan Record (Cambridge: Ballinger, 1984), 321-37; Steven E. Schier and Norman J. Vig, "Reviving Capitalism: Macroeconomic Policies in Britain and the United States," in Vig and Schier (eds.), Political Economy in Western Democracies, 182-94; Leys, "Thatcherism and British Manufacturing," 10-11; Heiner Bremer et al., Politik der Wende (Hamburg: Rasch und Roehring, 1985), 83-84; compare also, Paul Blumberg, Inequality in an Age of Decline (Oxford: Oxford University Press, 1980). 
dynamic of financial Darwinism. Unwilling to pay the high interest on investment credits and aided by antitrust deregulation, industrial capital has increasingly been used to buy up other firms rather than to finance expanding production. Further job losses are the consequence.

While it is premature to cast a concluding judgment on the performance and the impact of neo-conservative regimes on sectoral polarization, the record nevertheless seems indicative of the above generalizations. In the United States the rate of unemployment due to closings of manufacturing plants doubled between 1978-1980 and 1980-1982. Business bankruptcies reached record levels and continued undiminished during the upswing in 1983, even when they stalled in Britain. Merger and acquisition activities soared. Some corporations report higher earnings from financial activities than from industrial production. The picture in Britain is similar: mergers on the one hand and bankruptcies on the other. One difference is that crucial industries are sold off to American multinationals. Britain is rapidly becoming a branch-plant economy. The costs are mainly borne by manufacturing. Bankruptcies and liquidations more than doubled between 1978 and 1982. Manufacturing output fell by 14 per cent by 1983 . While official unemployment in Britain has risen beyond 13 per cent, it reached 20 per cent in overall manufacturing and over 33 per cent in metal manufacturing and engineering. Typically, the only sector which has increased its work force (by less than $2 \%$ ) is insurance, banking and finance. Declared as a year of recovery, 1984 also saw the highest rate of bankruptcies in the history of West Germany. While the profits of giant industries recovered formidably, banks reported a dangerous trend of decapitalization among middle-sized and small businesses. The Federal Cartel Agency reported an increased process of economic concentration. ${ }^{52}$

(3) Spatial disintegration is the inevitable side-effect of socioeconomic polarization and concentration due to the regional division of labour in advanced industrial systems. As capitalism spreads unevenly, centre-periphery relationships develop with peripheral development dependent on central control. In times of rapid expansion this dependency is usually characterized as one of manufacturing over

52 Palmer and Sawhill, The Reagan Record, 287-316; The Economist, February 25, 1984, 99; Candee S. Harris, "The Magnitude of Job Loss From Plant Closings and the Generation of Replacement Jobs: Some Recent Evidence," in "Deindustrialization: Restructuring the Economy," The Annals of the American Academy of Political and Social Science 475 (1984), 25-26; Rivlin, Economic Choices 1984, 119-33; Amott, "The Politics of Reaganomics," 177-79; Barry Bluestone and Bennet Harrison, The Deindustrialization of America (New York: Basic Books, 1982), 188-90; Leys, "Thatcherism and British Manufacturing," 12-13; David Rose et al., "Economic Restructuring: The British Experience," in "Deindustrialization: Restructuring the Economy," 144-45; Bremer et al., Politik der Wende, 30-31. 
primary production. Under conditions of scarcity, however, it is the control over finances, information flow and decision-making which characterizes centre-periphery dependency. This dependency becomes more visible when central responsibility and control is met with a declining capacity to fulfill expectations due to economic and fiscal constraints. When central decision-making becomes more selective, spatial polarization results from the conflict between contracting centres and resisting peripheries. This polarization is reinforced by the process of selective structural modernization.

The ongoing process of central contraction is most visible in Britain. In the traditional manufacturing region of the West Midlands, unemployment was 5 per cent higher than the national average by 1983 . The centrally controlled oil industry has helped to destroy much of the manufacturing industry by boosting the nondollar exchange rate by 41 per cent between 1979 and 1981. Central co-operation between state and multinational corporations aims at a national economic recovery ignorant and negligent of domestic manufacturing interests. In the words of Tom Nairn, the "metropolitan heartland complex" is being restructured into a "service-zone to international capital," while the industries of the peripheries "will eventually be shut down or sold off." Economic restructuring is complemented by a reversal of regional development policy. Drastic cuts in regional aid have become part of the economic recovery project. Regional polarization has also been noted in the United States. Different rates of economic growth/decline and the asymmetrical impact of the energy crisis on consumer/producer states have triggered a new salience of regional egotism and protectionism. Socioeconomically induced migration has particularly intensified interregional grievances. After having absorbed millions of unskilled rural workers from the south, the north is now in a process of losing its skilled workers-and its tax base-to the modernizing sunbelt. Reagan's "new" new federalism likewise contributes to these regional strains as the new concept of decentralization spells central spending concentration and peripheral austerity. The distress and inequity resulting from the regional mismatch between job loss and job creation have become accepted parts of the recovery programme. Melvyn Krauss, an economist with the Wall Street Journal, rejects regional policy as a nationally inefficient mode of bringing "work to the workers rather than hav[ing] workers go to the work." From the periphery, however, comes a different view. In the words of Dennis Kucinich, former mayor of Cleveland, Ohio, "There are increasingly two Americas,... the America of multinationals dictating decisions in Washington, and the America of neighbourhoods and rural areas, who feel left out."

The spatial effects of neo-conservative modernization are also being felt in West Germany-despite the country's relative structural 
homogeneity. The government-concerted strategy of recapturing the international competitiveness of the steel industry through drastic capacity reduction and concentration has resulted in disproportionately high regional and local unemployment. Tied into a recessionary cartel of corporatist restructuring, the unions had to share in a policy of massive regional job losses in order to save the stability of a contracting labour market in the steel sector as a whole. Hit by unemployment of up to 20 per cent, Germany's coastal region is suffering from particularly unpleasant effects of deindustrialization. While parts of its highly modern shipyards are dismantled and sold off to China, jobs are being offered for under-minimum wages by neighbouring wood-processing plants neither incorporated in the country's association of employers, nor bound by its tariff agreements. ${ }^{53}$

The neo-conservative record is ambiguous and clear-cut at the same time. It is ambiguous because monetarism engineers economic slow-down for the sake of reducing inflation, while supply-side tax-cuts (and military spending) seek to stimulate growth at the same time. It is unambiguously clear, however, that full employment as a policy priority has been abandoned. As the Commission of the European Community has pointed out, the goal is to achieve a relative change in the costs of labour and capital "via accepted levels of unemployment." ${ }^{54}$ Reagan's former chief economic adviser Murray L. Weidenbaum and American business expert Michael J. Athey go one step further by trying to uncouple the problem of unemployment from the agenda of economic restructuring altogether. In their view the health of the nation's industry has nothing to do with its unemployment rate: on the contrary, as productivity rises, employment necessarily has to decline..$^{55}$

The most pernicious aspect of this kind of economic reasoning is not its business-as-usual attitude, which downplays the social consequences of renewed market anarchy for the sake of factor mobility, but its

53 Stein Rokkan and Derek W. Urwin, Economy Territory Identity (London: Sage, 1983), 2-14; Rose et al., "Economic Restructuring," 145; Leys, "Thatcherism and British Manufacturing," 24-25; Tom Nairn, The Break-up of Britain: Crisis and Neo-Nationalism (London: NLB, 1977), 380; The Globe and Mail, Report on Britain, May 6, 1985; Etzioni, An Immodest Agenda, 163-73; Deil S. Wright and Harvey L. White (eds.), Federalism and Intergovernmental Relations (Washington: The American Society for Public Administration, 1984), 25; Harris, "The Magnitude of Job Loss From Plant Closings," 23-25; Krauss, "'Europeanizing' the U.S. Economy," 82; Kucinich, quoted in Peter N. Carroll, It Seems Like Nothing Happened (New York: Holt, Rinehart and Winston, 1982), 348; Josef Esser, Wolfgang Fach and Werner Vaeth, Krisenregulierung (Frankfurt/Main: Suhrkamp, 1983), 54-187; Bremer et al., Politik der Wende, 41.

54 Quoted in Elmar Altvater, Kurt Huebner and Michael Stanger, Alternative Wirtschaftspolitik jenseits des Keynesianismus (Opladen: Westdeutscher Verlag, 1983), 160 (my translation).

55 "What is the Rust Belt's Problem?" in Johnson (ed.), The Industrial Policy Debate, $121-23$. 
analytical blindness to the structural contradictions of market capitalism. On the one hand, the rhetoric of deregulation in reality has re-regulation in mind: the regulation of supply-side economics instead of aggregate demand. On the other hand, the supply-side approach is of little more than declaratory value. There is no guarantee that business uses the given incentives for employment-intensive investment - or for investment at all. The neo-conservative agenda can only suggest what ought to be done: "From here on, we require faith." 56

As they move from affluence to scarcity, and the polarizing patterns of structural change become visible, postindustrial societies and their governments have to contend with the contradictions of centralism and regionalism, mass society and fragmentation, continued class struggle and occupational/sectoral/regional conflict across classes, party retrenchment and new social movements, contraction and expansion of fragmented capitalist economies and the welfare state as their most important support system. Under such conditions a politics of fragmentation is likely to emerge which aims at the bifurcation of postindustrial societies. Signs are already visible: on the one hand a contracting core of productive efficiency which can expect to continue to survive with the benefits of the state's helping hand; and on the other hand an expanding periphery uncoupled from direct participation in the capitalist mode of production and confined to existing largely without such benefits.

\section{The Politics of Fragmentation}

The success of industrial capitalism has been based on spatial expansion, and on the exploitation of labour and resources. Dependent on growing centralization and monopolization, the "chain reaction" of increasing capital accumulation required the continued "enforcement of inequality." In other words, it became necessary to insulate capitalism from democratization. ${ }^{57}$ Increasingly the state had to perform the double task of ensuring economic growth (accumulation) and social stability (legitimation). But the visible interventionism of the state and the mobilizing dynamic of the industrialization process itself could not prevent a growing demand for political participation. This participatory demand was muted during the postwar years of exceptional growth and prosperity. It became reactivated (rather than newly created) through the attitudinal and structural defects of modernization. When it became threatened by economic crisis and scarcity, the chain reaction of accumulation had to be secured by new/old modes of insulation.

56 Robert Lekachman, Greed is Not Enough: Reaganomics (New York: Pantheon, 1983), 13.

57 See Andrew Martin, "Political Constraints on Economic Strategies in Advanced Industrial Societies," Comparative Politics 10 (1977), 323-54. 
The modernization project appears to be threatened from two sides: increasing subsistence demands from the less productive segments of the economy, and the persistent wage demands of organized labour. Consequently, there are two apparent patterns of insulation: a strategy of economic dualism via market deregulation and deflation, and/or a strategy of neo-corporatism aiming at the state-mediated regulation of industrial relations.

Deflationary and deregulatory strategies aim at the insulation of winners from losers. The paralyzing effects of such a cross-cutting dualization of labour and business are reinforced by an aggressive ideology of competitiveness. Where organized labour is weak and the cohesion of business low, as in Britain and the United States, the strategy of economic bifurcation is met with little resistance. Where labour is organized and strong, on the other hand, as in West Germany for example, a different strategy of adjustment is required. Alternately labelled as "organized capitalism" or "corporatism," it relies on hierarchically controlled modes of political bargaining instead of market deregulation, and on an ideology of social partnership instead of competitiveness. ${ }^{58}$

The result of both strategies is the same, however: the growing bifurcation of late capitalist societies into a dominant segment sanctioned politically with a quasi-public status, and a residual segment increasingly uncoupled from the capitalist exchange relationship. Again, liberal and radical views differ substantively as to the structural impact and social character of these recent trends of interest intermediation and economic stabilization.

\section{Economic Dualism}

The idea of economic dualism is unacceptable to the orthodox economic mind. There is only one labour market in which everybody competes against everybody else, and everybody is rewarded by a wage according to personal skills or "human capital." In other words, poverty, unemployment and segmented industrial labour markets do not stem from economic barriers to labour mobility such as the sectoral division between high-pay monopoly industries and the low-pay industries in the competitive sector. Unemployment and poverty are rather seen as a consequence of the politically induced "downward rigidity" of wages. Government subsidization of wages in "low-productivity uses" prevents labour from being forced to move into "areas of higher

58 For a recent definition and analysis see Peter J. Katzenstein, Small States in World Markets (Ithaca: Cornell University Press, 1985), 31-33. Incidentally, Katzenstein relies almost entirely on the orthodox view of "liberal" corporatism; it seems to be a pattern that "liberal" corporatists usually ignore their radical critics: see below, notes 62-67. 
productivity." From the economic restructuring point of view, government tinkering with the labour market is unwanted and inefficient: "The winners do not need such help." 59

The symptoms of economic dualization are particularly evident in strongly regionalized economic systems such as Canada, where orthodox economists have consistently renounced peripheral job market stabilization as inefficient "transfer dependency." Firmly based on the theoretical axiom of single market homogeneity, they plead for peripheral-and national-economic recovery via the lowering of minimum wages and forced migration. ${ }^{60}$ At least implicitly, this strategy aims at the permanent establishment of a dual labour market: with desirable high-pay sectors at the core and undesirable low-pay sectors at the periphery. The economic viability and efficiency of such a strategy appear doubtful. Migration is most likely to occur when unemployment is high in core areas as well. Those at the lowest end of income and skills will prove to be least mobile. And finally, public cost might be increased rather than lowered when permanent unemployment at the core must be subsidized rather than seasonal unemployment in the periphery.

From the radical point of view economic dualism is part of the industrial modernization project itself. As evidence of expanding employment in some sectors of light manufacturing and the service industries indicates, low wages are not inevitably linked to unemployment in declining sectors. Low-wage sectors rather seem to survive due to the excess of workers dismissed from the contracting core industries. The cleavage lines of the dual economy do not simply run between growing and declining sectors, but between workers in weak and strong sectors, weak and strong firms, large and small businesses, competing production units, or simply between "ins" and "outs."

Contrary to the liberal assumptions of market homogeneity, the record shows quite clearly that persistent tendencies of market dualism contributed to the exceptional growth of the postwar period, and that they have become even more entrenched under the conditions of recent economic decline and crisis. The main features of utilizing dual labour markets for purposes of growth and productivity are: (1) migrant workers who can be instrumentalized as a "reserve labour army" during

59 See Paul Attewell, Radical Political Economy Since the Sixties (New Brunswick: Rutgers University Press, 1984), chap. 2; Lester C. Thurow, The Zero-Sum Society (Harmondsworth: Penguin, 1980), 54-61; and Kraus, '“Europeanizing' the U.S. Economy," 82-90.

60 See the critical discussion in Ralph Matthews, The Creation of Regional Dependency (Toronto: University of Toronto Press, 1983), 56-68; compare Thomas J. Courchene, "Analytical Perspectives on the Canadian Economic Union," in Michael J. Trebilcock et al. (eds.), Federalism and the Canadian Economic Union (Toronto: Ontario Economic Counil, 1983), esp. 91-93; and recently by the same author, "The Fiscal Arrangements: Focus on 1987," in Ottawa and the Provinces: The Distribution of Money and Power (Toronto: Ontario Economic Council, 1985), vol. 1, 3-21. 
boom years and sent home during periods of decline (both transnationally, as in Europe, and internally, as between Atlantic and central Canada); (2) subcontracted small businesses which offer nonunionized employment, flexible wages and exemptions from health and safety regulations as a structural insurance of the core economy against fluctuations in demand, and (3) marginal and temporary workers who are to a large extent deprived of the legal protections of permanent employment. They may work at home, seek work through "labour-only" subcontracting businesses, or operate on the black market. ${ }^{61}$

It is the ideology of competitiveness which ultimately stabilizes the politics of economic dualism in fragmented capitalist societies. The aggregate level of complexity in such societies makes it extremely difficult for the various segments of capital to assess in advance the consequences of such renewed market strategies as free trade and deregulation. While everybody hopes to be on the winning side, the only real winners are those economic sectors which in fact remain insulated from the whims of the market because they possess monopoly and/or multinational status. When this status is challenged by organized labour, as in the case of West Germany, regulation must be achieved through a contractive mechanism of corporatist intermediation.

\section{Neo-corporatism}

Commonly understood as a new form of economic crisis management, corporatism describes state-mediated forms of political bargaining between organized capital and labour. Liberal analysis understands it as a new "logic of exchange" which can only be successful if symmetrical rewards are granted to both partners at the negotiating table. The success of corporatist strategies is held to depend on multiple consensus requirements. The "amicable" social partnership between capital and labour must be paralleled by consensual co-operation among the political parties (government and opposition), and supported by the rank and file within the ideological "camps" (parties and organized interests). While the state-licensed participants in corporatist bargaining schemes gain a quasi-public status, the process of interest intermediation itself remains largely informal. ${ }^{62}$

61 Attewell, Radical Political Economy Since the Sixties, chaps. 2-3; Streeck, "Neo-Corporatist Industrial Relations and the Economic Crisis in West Germany," 310-14; John H. Goldthorpe, "The End of Convergence: Corporatist and Dualist Tendencies in Modern Western Societies," in Goldthorpe (ed.), Order and Conflict in Contemporary Capitalism, 329-35.

62 See esp. Gerhard Lehmbruch, "Concluding Remarks: Problems for Future Research on Corporatist Intermediation and Policy-Making," in Philippe C. Schmitter and G. Lehmbruch (eds.), Trends Toward Corporatist Intermediation (Beverly Hills: Sage, 1979), 305; and G. Lehmbruch, "Concertation and the Structure of Corporatist 
This idyllic picture of integrating labour organizations into the economic decision-making process of organized capitalism seems to fall short of a realistic assessment in at least two aspects. First, it is painted against the background of a flawed perception of pluralism (from which corporatism wants to be distinguished conceptually). Defining pluralism as a regime of group competition largely unrestrained from state intervention and control, orthodox neo-corporatists neglect the dominant role of business over all other groups. They start from conceptual assumptions which the liberal school itself has long left behind. ${ }^{63}$ Second, the picture of interest intermediation through quasi-formal labour incorporation further neglects the informal aspects of state intervention (rather than mediation) in labour-market organization which principally restrict the manoeuverability of trade unions.

Radical analysts emphasize that neo-corporatism is nothing but the continuation of capitalist class domination with other means: an alternative strategy of labour subordination when the "classic pattern of control through markets" fails. ${ }^{64}$ Since this pattern of control hardly qualifies the market exchange relationship in capitalist societies as "pluralist" in the classical sense, neo-corporatism must at least be seen as a continuation of pluralism with other means: a state-mediated strategy of reducing "excessive democracy" and "governmental overload" by limiting the number of legitimate participants in economic policy-making. The dilemma of the liberal corporatist school can therefore be summarized as a contradiction between the conceptual "logic of exchange" and the evident "logistics of business domination." Orthodox neo-corporatists try to circumvent this dilemma by pointing

Networks," in Goldthorpe (ed.), Order and Conflict in Contemporary Capitalism, 60-80; for the classical definitions and discussion, see the articles by Philippe $\mathrm{C}$. Schmitter and G. Lehmbruch, in Schmitter and Lehmbruch (eds.), Trends Toward Corporatist Intermediation, and in Lehmbruch and Schmitter (eds.), Patterns of Corporatist Policy-Making (London: Sage, 1982).

63 See Robert A. Dahl, Dilemmas of Pluralist Democracy (New Haven: Yale University Press, 1982); Charles Lindblom, Politics and Markets (New York: Basic Books, 1977). For a critical discussion of these authors, see John F. Manley, "Neo-Pluralism: A Class Analysis of Pluralism I and Pluralism II," American Political Science Review 77 (1983), 368-83; a useful critique of the conceptual flaws of neo-corporatism is Stephen McBride, "Corporatism, Public Policy and the Labour Movement: A Comparative Study," Political Studies 33 (1985), 439-56.

64 Colin Crouch, "The State, Capital and Liberal Democracy," in Crouch (ed.), State and Economy in Contemporary Capitalism, 19; see also Wolfgang Fach, "Ausgangspunkte des Diskurses, Ende des Modells?" Journal fuer Sozialforschung 23 (1983), 385-88; Hans Kastendiek, Hella Kastendiek and Hugo Reister, "Incorporation of the Trade Unions?" (Frankfurt/Main: Institut fuer Sozialforschung, 1983); Leo Panitch, "Corporatism and Capitalist Democracy," paper presented at the World Congress of the International Political Science Association, Rio de Janeiro, 1982. 
out that corporatist strategies may only succeed if some form of symmetrical exchange is achieved, and by at least tacitly acknowledging that this may not always be the case.

Radical analysts, on the other hand, emphasize that such symmetry is certainly not the intention of corporatist strategy. On the contrary, the goal of corporatist intermediation is viewed as negatively as that of the regime of market exchange: as the insulation of the capitalist accumulation process from "excessive" participatory demands. The neo-corporatist strategy thus aims at bifurcation by concertation. Rather than attempting to achieve multiple consensus, corporatism seeks to eliminate those segments of society from participation which are no longer seen as essential for the accumulation process. Horizontally, it seeks to insulate the economic core from peripheral demands. The choices of liberal democracy are subordinated to an industrial modernization project controlled by a cartelized elite of major economic interests which have gained quasi-public status. Vertically, it shields the bargaining elite from rank-and-file expectations. The constraints of the required consensus force the unions to abandon interest representation for the unskilled and unemployable, and they allow the dominant economic interests to neglect the concerns of small and declining businesses. "Liberal" corporatism appears as the contracting strategy of a highly selective "corporatist bloc." 65

The main analytical strength of the neo-corporatist school has been its emphasis on the continued existence of structural patterns in advanced capitalist systems which tie organized labour into the state and business-dominated network of economic policy-making. The suggestion of a liberal "logic of exchange" remains misleading, however, because it implies that the asymmetrical disadvantage of labour in capitalist systems is somehow overcome. It is moreover contradictory, because a strategy of licensed overload reduction scarcely conforms to the pluralist ideology of liberalism-neither in its naive variety, assuming unrestrained interchange among a plurality of group organizations, nor in the refined version which suggests such interchange among alternating elites.

But the main fallacy of orthodox neo-corporatism lies elsewhere: in the assumption that corporatist arrangements can only be successful when class polarization is neutralized by mutual amicability and consensus. Such an assumption misconceives the asymmetrical nature of the exchange relationship between capital and labour in liberal regimes; analytically it takes for amicability what in reality is dictated by the structural constraints and contradictions of crisis capitalism. Late

65 Josef Esser and Wolfgang Fach, "Korporatistische Krisenregulierung im "Modell Deutschland'," in Ulrich von Alemann (ed.), Neokorporatismus (Frankfurt/Main: Campus, 1981), 158-79 (my translation). 
insights into the potentially undemocratic nature of neo-corporatism (accountability "to the wrong collectivities," and responsiveness "to the wrong needs") do not substantially change the picture as long as the assumption is maintained that neo-corporatism may have "equalized [the] access to policy-making in advanced capitalist societies." 66

More adequately, the neo-corporatist paradigm appears as a "heuristic tool" for the analysis of state-controlled industrial relations in advanced capitalist societies, and neo-corporatist practice as a "class concept" aiming at the hierarchical stabilization of such societies. ${ }^{67}$ Neo-corporatism may operate amicably as long as the accumulation process is not seriously challenged. When this is the case, however, and when the concept of market duality cannot be attained through neo-laissez-faire strategies, corporatism becomes a selective bypass operation for the clogged channels of liberal policy formation.

\section{Conclusion}

Both the dualist and neo-corporatist variants of competitive economic restructuring reveal an emerging picture of sociopolitical fragmentation in Western industrial societies. Capitalist politics appears to be haunted by an interrelated set of contradictions which cannot be rationalized away by the surface evidence of neo-conservative government stability. What the crisis of scarcity ultimately brings to the fore is an incompatibility of liberal democracy (form) and capitalism (content) which has been veiled by the relative success of capitalist expansion. The politics of fragmentation by selective restructuring (efficiency) leads to a structural decline of co-operation and consensus (legitimacy). Paradoxically, every effort to reintegrate the segments of society into a market exchange relationship seems to increase the number of those which are no longer determined by it. ${ }^{68}$ Increasingly, the logic of exchange has to be secured by the logistics of regulatory support systems.

While neither a complete dismantling of the intervention state nor a radical transformation of the capitalist system can be expected in the foreseeable future, the crisis of the capitalist welfare state seems to move very quickly from a situation of neo-conservative concern over the perceived dilemmas of public demand and governmental overload to an objective condition of structural contradictions and policy immobilism. Thus, while the present round of conservative governments might soon become replaced by the previous coalitions of liberalism and social

66 Philippe C. Schmitter, "Democratic Theory and Neo-Corporatist Practice," EUI Working Paper 74 (Florence: European University Institute, 1983), 55-56.

67 Leo Panitch, "Corporatism in Canada," Studies in Political Economy 1 (1979), 44-45; and Crouch, "The State, Capital and Liberal Democracy," 19.

68 Compare Offe, Contradictions of the Welfare State, 284-86. 
democracy, the latter will be confronted with a bitter heritage which might reveal the obsolescence of the logic of the capitalist welfare state even more rapidly: Mitterrand's France has learnt that lesson already.

Both sides-governments and societies, capital and labour, centres and peripheries, winners and losers-are inextricably intertwined in this web of contradictions, and increasingly disenchanted with each other at the same time. A bifurcated society which is at the same time becoming more disaggregated and interdependent, seems to be the most plausible scenario for advanced industrial systems at the turn of the next century-an unsatisfactory result for a tidy analytical mind. 